\title{
Perbandingan Perhitungan Trafik Jam Sibuk CDMA 2000 1x pada BTS Inner City dan BTS Outer City dengan Mempergunakan Metode ADPH, TCBH, FDMH dan FDMP
}

\author{
Eka Wahyudi ${ }^{1}$, Wahyu Pamungkas ${ }^{2}$, Adimawono Basuseno ${ }^{3}$ \\ ${ }^{1,2,3}$ Sekolah Tinggi Teknologi Telematika Telkom \\ Jl. D.I. Panjaitan No. 128 Purwokertro, Banyumas, Jawa Tengah, Indonesia \\ 1ekawahyudi@st3telkom.ac.id, 2wahyu@st3telkom.ac.id
}

\begin{abstract}
Cellular communication system is a wireless communication system where the subscriber can move within a wide network coverage. Code Division Multiple Access (CDMA) is a multiuser access technology that is each user uses a unique code contained in the access channel in the system. Calculation and determination of peak hours can be done by several methods such as: Average Daily Peak Hour (ADPH), Time Consistent Busy Hour (TCBH), Fixed Daily Measurement Hour (FDMH), Fixed Daily Measurement Period (FDMP). The effectiveness of the channel should be determined by occupancy both at inner city territory and outer city territory location. Using design Erlang (Erl) for supply channel at Base Transceiver Station (BTS) that provided, BTS has a design Erlang of 369,83 Erl at inner city and it has a design Erlang of 241,8 Erl at outer city. Peak hour on the inner city occurred at 12:00 to 15:00, whereas the outer city of peak hour occurred at 18:00 to 21:00. Effectiveness value that determined by operator are : $<20 \%=$ low occupancy (not effective), $21 \%$ to $69 \%=$ normal occupancy (effective), and $>70 \%=$ high occupancy (very effective). In this case occupancy values obtained in each method is between $21 \%$ to 69\% which means effective.
\end{abstract}

Keyword: CDMA, ADPH, TCBH, FDMH, FDMP, Inner City, Outer City, design Erlang

\section{PENDAHULUAN}

Kemajuan teknologi dewasa ini sangat mempengaruhi kehidupan manusia, khususnya di bidang telekomunikasi, yang memegang peranan penting dalam kegiatan sehari-hari, terutama dalam hal komunikasi suara antar manusia (voice). Dengan teknologi telekomunikasi, manusia dapat bertukar informasi dalam bentuk satu sama lain sekalipun dengan jarak yang jauh. Telepon sebagai perangkat telekomunikasi merupakan salah satu media komunikasi yang mengirimkan/menerima pesam suara. Seiring perkembangan zaman, teknologi perantara telepon terbagi dalam 2 jenis yaitu, telepon kabel dan telepon nirkabel (bergerak).
Pada penelitian ini, akan dibahas mengenai telepon bergerak yang menggunakan teknologi Code Division Multiple Access (CDMA). CDMA adalah teknologi akses multiuser yaitu masing-masing user menggunakan code yang unik dalam mengakses kanal yang terdapat dalam sistem. Teknologi CDMA mempunyai beberapa kelebihan yaitu memiliki kapasitas yang lebih besar dengan sistem penggandaan kanal melalui pembagian waktu pada frekuensi yang sama.

Untuk menilai performansi jaringan yang sudah ada perlu adanya pengecekan pada faktor konsentrasi, dengan melihat dari perbandingan jumlah pelanggan dan kapasitas kanal yang disediakan. Apabila terdapat ketidakseimbangan antara jumlah pelanggan dengan kanal yang telah disediakan maka dapat dilakukan penambahan kapasitas kanal ataupun pemindahan pelanggan ke jaringan yang masih memiliki banyak kanal komunikasi. Untuk dapat mengetahui nilai performansi tersebut maka dapat dilihat dari nilai trafik yang telah dibangkutkan oleh pelanggan yaitu dengan melihat trafik originating dan terminating. Trafik originating merupakan proses panggilan keluar yang dilakukan oleh pelanggan untuk dapat berkomunikasi dengan pelanggan lain, sedangkan trafik terminating dapat berupa proses panggilan masuk yang berarti pelanggan lain ingin berkomunikasi dengan pelanggan lainnya.

Kondisi trafik ini untuk setiap lokasi Base Transceiver Station (BTS) berbeda-beda satu tama lain. Untuk BTS dalam kategori inner city atau suatu BTS yang berada di pusat kota memiliki perilaku trafik yang berbeda dengan BTS outer city yang merupakan BTS yang berada di pinggiran kota. Hal ini disebabkan karena populasi pembangkit trafik di daerah inner city lebih padat dibandingkan di daerah outer city. Dalam penentuan besaran trafik pada kedua daerah tersebut dapat dipergunakan beberapa motode perhitungan. Beberapa metode perhitungan yang dapat dipergunakan adalah sebagai berikut:

- Average Daily Peak Hour (ADPH) yang merupakan metode perhitungan jam tersibuk yang ditentukan berbeda-beda untuk setiap harinya, lalu dirata-ratakan selama waktu pengamatan. 
- Time Consistent Busy Hour (TCBH) merupakan perioda satu jam, yaitu perioda ini sama untuk setiap harinya yang memberi hasil pengukuran trafik rata-rata tertinggi selama perioda pengamatan.

- Fixed Daily Measurement Hour (FDMH) adalah perioda pengamatan telah ditentukan sebelumnya waktu pengamatan selama selang waktu 1 jam. Misalnya, asumsi antara jam 9.30 - 10.30, trafik hasil pengukuran dirataratakan selama perioda pengamatan.

- Fixed Daily Measurement Period (FDMP) adalah metode pengukuran yang dilakukan dalam waktu tertentu (misalnya 3 jam) setiap hari. Waktu ini harus sesuai dengan bagian tertinggi dari profil trafik yang dihasilkan dari perhitungan dengan metode $\mathrm{TCBH}$ sebelumnya. Selanjutnya pengukuran nilai diakumulasikan secara terpisah untuk setiap jam, dan jam tersibuk ditentukan pada akhir periode pengukuran.

Dengan membandingkan keempat metode tersebut akan dapat diketahui keefektifan kanal yang digunakan dan dapat ditentukan jam sibuk selama waktu pengamatan, baik untuk BTS di daerah inner city ataupun di daerah outer city.

\section{METOdOLOGI PENULISAN}

Dalam penelitian ini, untuk mendapatkan solusi dari permasalahan, dipergunakan tahap-tahap penelitian yang terdiri dari:

\section{- Observasi}

Observasi yang dilakukan yaitu dengan melakukan pengamatan terhadap kanal trafik suara dan data yang disediakan maupun yang terpakai oleh pelanggan.

\section{- $\quad$ Studi Literatur}

Studi literatur dilakukan dengan mempelajari teoriteori dasar yang dipergunakan sebagai landasan teori.

\section{- Analisis}

Analisis yang digunakan adalah metode penjabaran atau metode deskriptif. Dengan menggunakan metode ini akan dijelaskan mengenai kondisi trafik yang digunakan dan mengenai kondisi jam sibuk dengan mengamati data total trafik yang meliputi trafik suara (voice) dan trafik data.

Sedangkan untuk tahapan penelitian yang dilakukan yaitu pada tahap awal penelitian terlebih dahulu dilakukan studi literatur, selanjutnya dilanjutkan dengan studi observasi lapangan untuk mempeajari kasus yang akan diselesaikan ataupun untuk melakukan verifikasi atas dugaan permasalahan, guna memperoleh pemahaman dan proses analisis lebih lanjut. Pada tahap analisis tersebut dilakukan analisis terhadap hasil data yang telah diperoleh untuk mendapatkan kesimpulan atas permasalahan yang diteliti.

\section{DASAR TEORI}

\section{A. Sistem Komunikasi Selular}

Sistem komunikasi selular merupakan sistem komunikasi bergerak yang memberikan layanan kepada pengguna. Karakteristik utamanya adalah dapat melakukan komunikasi secara bebas dalam area layanan tanpa adanya batasan jarak serta tanpa adanya pemutusan hubungan. Perkembangan teknologi komunikasi bergerak bermula dengan digunakannya metode sel dan transmisi analog dalam pengiriman informasi. Masa ini disebut generasi pertama atau $1 \mathrm{G}$ dimana Advanced Mobile Telephone System (AMTS) menjadi teknologi yang terkenal saat itu. Kemudian diperkenalkanlah metode transmisi digital dalam pengiriman informasi yang menandai dimulainya era generasi kedua atau 2G. Global System for Mobile Communication (GSM) menjadi teknologi yang mendominasi era ini. Pada era ini pula mulai diperkenalkan konsep Code Division Multiple Access (CDMA).

Seiring dengan peningkatan kebutuhan, telepon selular tidak lagi hanya berfungsi sebagai alat untuk mengirim suara dan teks, tapi juga sebagai alat untuk bertukar data. Untuk mengakomodasi kebutuhan itu, diciptakanlah konsep 3G yang memungkinkan pengguna untuk mengirimkan data suara dan non suara secara simultan. Contoh teknologi pada era ini adalah CDMA 2000 1X EV-DO, WCDMA, dan $\mathrm{UMTS}^{[1]}$.

Pada dasarnya telepon selular memiliki transmisi spektrum sumber daya terbatas, yang harus digunakan bersama oleh beberapa pengguna. Tidak seperti komunikasi kabel yang mempunyai kegunaan dari isolasi yang disediakan oleh kabel, pengguna nirkabel dalam jarak dekat satu sama lain dapat menyebabkan gangguan yang signifikan satu sama lain. Untuk mengatasi masalah ini, konsep komunikasi selular diperkenalkan sekitar tahun 1968 oleh para peneliti di Laboratorium AT \& T Bell. Konsep dasarnya adalah bahwa geografi yang diberikan dibagi menjadi poligon yang disebut sel.

Setiap sel dialokasikan sebagian dari spektrum frekuensi total. Agar pengguna pindah ke sel yang telah ditentukan, kemudian pengguna diizinkan untuk memanfaatkan kanal yang di alokasikan ke sel itu. Keutamaan dari sistem selular adalah bahwa sel yang berbeda dapat menggunakan kanal yang sama mengingat bahwa sel-sel yang dipisahkan oleh jarak minimum sesuai dengan sistem karakteristik propagasi. Jika tidak, interferensi antar selular cochannel akan terjadi. Jarak minimum yang diperlukan untuk mengurangi gangguan co-channel disebut pengulangan jarak (reuse distance). Reuse distance didefinisikan sebagai rasio jarak (D), antara sel-sel yang dapat menggunakan kanal yang sama tanpa menyebabkan gangguan dan radius sel (R). (R) adalah jarak dari pusat sel ke titik terluar dari sel pada suatu kasus ketika sel tidak mencakupi area seluruhnya.

Alokasi kanal berkaitan dengan alokasi kanal untuk sel-sel dalam jaringan selular. Setelah kanal 
yang dialokasikan, sel-sel kemudian dapat memungkinkan pengguna dalam sel untuk berkomunikasi melalui kanal yang tersedia. Kanal dalam sistem komunikasi nirkabel biasanya terdiri dari time slots, pita frekuensi atau CDMA pseudo noise sequences, tetapi dalam arti yang abstrak, sistem komunikasi nirkabel dapat mewakili setiap sumber daya transmisi generik. Ada tiga kategori utama untuk menetapkan kanal pada sel (BTS), yaitu :

\section{- $\quad$ Fixed Channel Allocation (FCA)}

FCA adalah sistem pengalokasian kanal khusus untuk sel-sel spesifik. Alokasi ini adalah statis dan tidak dapat diubah. Untuk operasi yang efisien, sistem FCA biasanya mengalokasikan kanal dengan cara yang memaksimalkan frekuensi reuse. Jadi, dalam sistem FCA, jarak antara sel-sel menggunakan kanal yang sama adalah jarak minimum untuk menggunakan kembali sistem itu.

\section{- Dynamic Channel Allocation (DCA)}

DCA berguna untuk mengatasi masalah yang ditimbulkan pada sistem FCA ketika trafik yang ditawarkan tidak seragam. Dalam sistem DCA, tidak ada hubungan antara kanal dan sel. Sebaliknya, kanal adalah bagian dari sumber daya trafik. Setiap kanal yang dibutuhkan oleh sel, kanal dialokasikan pada batasan permasalah bahwa frekuensi reuse tidak dapat dilanggar. Ada dua masalah yang biasanya terjadi dengan sistem berbasis DCA. Metode DCA biasanya memiliki tingkat keacakan yang berhubungan dengan sistem komunikasi selular dan ini mengarah pada fakta bahwa frekuensi reuse sering tidak dimaksimalkan seperti kasus untuk sistem FCA di mana sel-sel menggunakan kanal yang sama dipisahkan oleh distance reuse minimal. Metode DCA sering melibatkan algoritma kompleks untuk menentukan kanal yang tersedia yang paling efisien. Algoritma ini bisa sangat komputasi intensif dan mungkin memerlukan sumber daya komputasi yang besar untuk menjadi real-time.

\section{- Hybrid Channel Allocation (HCA)}

Kategori ketiga metode alokasi kanal mencakup semua sistem hybrid dari sistem kanal tetap dan alokasi dinamis. Beberapa metode telah disajikan yang termasuk dalam kategori ini dan di samping itu, banyak perbandingan telah dibuat dengan simulasi yang sesuai dengan analisis.

Peminjaman kanal adalah salah satu skema paling mudah alokasi hybrid. Di sini, kanal ditugaskan ke selsel seperti dalam skema alokasi tetap. Jika sel membutuhkan kanal lebih dari kanal yang sebelumnya ditugaskan untuk itu, sel yang dapat meminjam kanal dari salah satu sel tetangganya mengingat bahwa kanal yang tersedia dan penggunaan kanal ini tidak akan melanggar persyaratan penggunaan frekuensi reuse. Karena setiap kanal memiliki hubungan yang ditentukan dengan sel tertentu, peminjaman kanal (tanpa ekstensi) sering dikategorikan sebagai subclass dari skema alokasi tetap. Masalah utama dengan peminjaman kanal adalah bahwa ketika sel meminjam kanal dari sel tetangga, sel terdekat lainnya dilarang menggunakan kanal yang dipinjam karena akan menyebabkan interferensi co-channel. Hal ini dapat menyebabkan blocking call. Untuk mengurangi blocking call, algoritma diperlukan untuk memastikan bahwa kanal yang dipinjam dari sel tetangga yang paling tersedia yaitu, sel-sel tetangga dengan kanal yang tidak sedang digunakan.

\section{B. Sistem CDMA $20001 X$}

Code Division Multiple Access (CDMA) merupakan salah satu teknik multiple access yang banyak diaplikasikan untuk selular maupun fixed wireless. Konsep dasar dari teknik multiple access yaitu memungkinkan suatu titik dapat diakses oleh beberapa titik yang saling berjauhan dengan tidak saling mengganggu. Teknik multiple access mempunyai arti bagaimana suatu spektrum radio dibagi menjadi kanal-kanal dan bagaimana kanalkanal tersebut dialokasikan untuk pelanggan sebanyak-banyaknya dalam satu sistem ${ }^{[2]}$.

CDMA 2000 adalah platform wireless yang termasuk ke dalam kelompok spesifikasi International Mobile Telecommunication 2000 (IMT-2000) dan merupakan pengembangan dari standar platform wireless CDMA IS-95. Teknologi transmisi radio CDMA 2000 adalah teknologi wideband dengan teknik spread spectrum yang memanfaatkan teknologi CDMA untuk memenuhi kebutuhan layanan sistem komunikasi wireless generasi ketiga (3G) yang berupa aplikasi layanan multimedia. Sistem CDMA 2000 mencakup implementasi luas yang ditujukan untuk mendukung data rate baik untuk circuit switched maupun packet switched dengan memanfaatkan data rate mulai dari 9,6 kbps (TIA/EIA-95-B) sampai lebih dari 2 Mbps. Beberapa layanan yang dapat didukung antara lain, wireless internet, wireless e-mail, telemetry dan wireless commerce ${ }^{[2]}$.

\section{Arsitektur Jaringan CDMA $20001 X$}

Skema struktur jaringan CDMA 2000 1X secara umum terdiri dari (Gbr 1-2):

- User terminal

- $\quad$ Radio Access Network (RAN)

- $\quad$ Circuit Core Network (CCN)

- Packet Core Network (PCN)

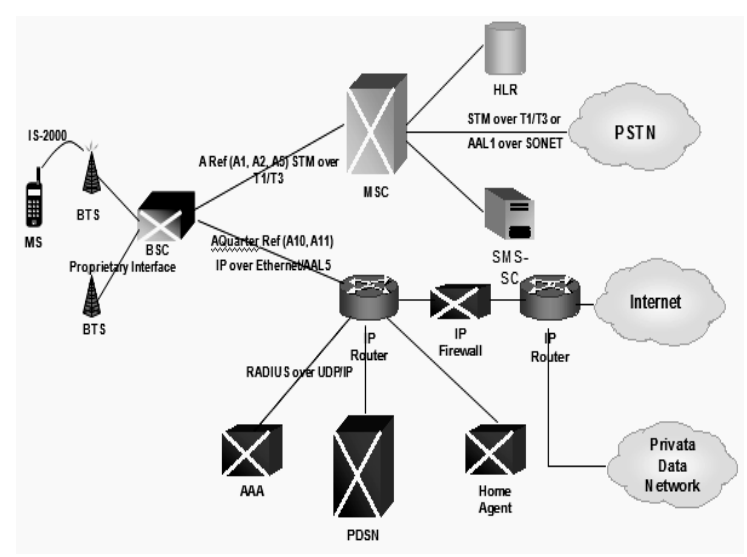

Gambar 1. Arsitektur CDMA $20001 \mathrm{X}^{[3]}$ 


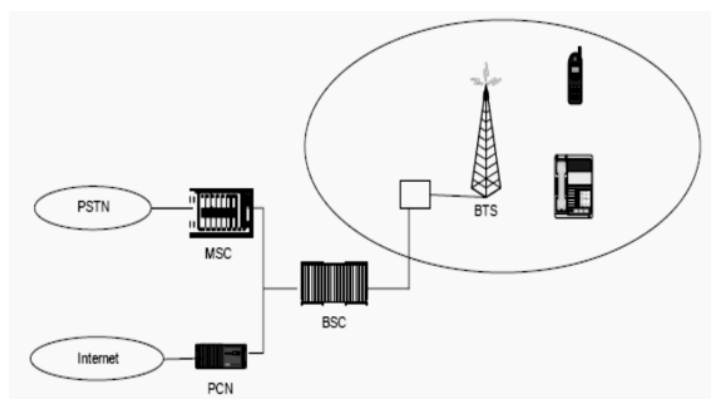

Gambar 2. Konfigurasi Jaringan Observasi

\section{Trafik pada Selular}

Secara sederhana trafik dapat diartikan sebagai pemakaian. Pemakaian yang diukur dengan waktu (berapa lama, kapan), yang tentunya dikaitkan dengan apa yang dipakai dan dari mana, ke mana. Besaran dari suatu trafik telekomunikasi diukur dengan satuan waktu, sedangkan nilai trafik dari suatu kanal adalah lamanya waktu pendudukan pada kanal tersebut. Salah satu tujuan perhitungan trafik adalah untuk mengetahui unjuk kerja jaringan dan mutu pelayanan jaringan telekomunikasi. Dalam sistem telepon, panggilan yang datang biasanya tak dapat ditentukan terlebih dahulu tentang kapan dan berapa lama suatu pembicaraan telepon berlangsung atau berapa lama suatu perlengkapan/kanal diduduki ${ }^{[4]}$.

Nilai trafik dari suatu berkas kanal adalah banyaknya (lamanya) waktu pendudukan yang diolah oleh berkas kanal tersebut. Beberapa istilah trafik antara lain yaitu:

- Volume trafik : Jumlah waktu pendudukan

- Intensitas trafik : Jumlah waktu pendudukan per satuan waktu

Volume trafik (V) dapat juga didefinisak sebagai jumlah lamanya waktu pendudukan perangkat telekomunikasi (total holding time) dengan holding time = durasi panggilan dan pangggilan $($ call $)=$ koneksi dalam sistem teletraffic. Sedangkan intensitas trafik merupakan suatu besaran yang merupakan ukuran dari kepadatan trafik. Intensitas trafik juga didefinisikan sebagai perbandingan antara lamanya waktu pendudukan rata-rata panggilan dengan selang waktu interval atau periode waktu pengamatan, dimana waktu pengamatan umumnya dilakukan selama 60 menit (satu jam).

\section{E. Pengertian Erlang}

Erlang adalah satuan kepadatan trafik dalam suatu sistem telekomunikasi. Satu erlang adalah setara dengan satu panggilan (termasuk upaya panggilan dan holding time) dalam kanal khusus untuk 3600 detik dalam satu jam ${ }^{[5]}$. Seiring berjalannya waktu, satu Erlang dapat menduduki nol, satu atau beberapa kanal. Definisi dari satuan erlang tidak menampilkan tentang bagaimana prilaku trafik dari rata-rata statistik ini. Jadi satu erlang dapat dihasilkan misalnya dengan satu panggilan mempunyai durasi yang tidak terbatas atau sebuah proses yang dilakukan secara acak dengan banyak panggilan datang dan panggilan berakhir, sehingga rata-rata jumlah panggilan aktif adalah satu kanal.

Terdapat 3 (tiga) jenis satuan Erlang dengan fungsinya masing-masing, yaitu :

- Erlang-A berfungsi sebagai penanganan panggilan yang datang untuk mengisi kanalkanal yang kosong dan apabila kanal sudah terpenuhi tidak tersedia kanal lagi, maka panggilan yang datang akan mengalami penolakan panggilan dan antrian panggilan. Dari penolakan dan antrian panggilan inilah Erlang-A menjalankan fungsinya untuk mengatur penggunaan panggilan yang ditolak dan panggilan yang mengantri agar mendapatkan kanal komunikasi ${ }^{[6]}$.

- Erlang-B berfungsi sebagai pemblokiran atau penolakan panggilan datang yang tidak mendapatkan kanal komunikasi. Penolakan panggilan ini berfungsi sebagai pertanda agar pengguna tidak melakukan panggilan selama waktu itu dan bisa mencoba melakukan panggilan beberapa saat kemudian. Untuk saat ini Erlang-B lebih banyak digunakan daripada dua jenis Erlang lainnya. Erlang-A mempunyai tugas sebagai penanganan panggilan, penanganan panggilan merupakan cara yang menggunakan pelayanan operator (call center). Apabila ada 100 panggilan yang ditolak akan membutuhkan 100 orang operator untuk menangani panggilan datang untuk mendapatkan kanal komunikasi. Sedangkan Erlang-C berfungsi sebagai pengatur antrian panggilan yang tidak mendapatkan kanal, jika panggilan mengantri dengan waktu yang lama akan memberikan kerugian bagi pelanggan dari segi materi dan waktu. Maka dari itu, yang efektif untuk saat ini adalah penolakan panggilan datang apabila kanal sudah penuh ${ }^{[5]}$.

- Erlang-C berfungsi sebagai pengatur antrian panggilan datang yang tidak mendapatkan kanal komunikasi. Panggilan datang yang tidak mendapatkan kanal komunikasi ini akan mengantri sampai dapat dilayani. Ini berlawanan dengan sistem Erlang-B, yaitu panggilan datang langsung ditolak ${ }^{[5]}$.

\section{F. Metode Penentuan Jam Sibuk}

Dalam penentuan jam sibuk, dipergunakan empat jenis metode perhitungan, yaitu :

\section{1) Average Daily Peak Hour $(A D P H)^{[7]}$}

Jam tersibuk ditentukan berbeda-beda untuk setiap harinya (Different Time For Different Days), lalu dirata-ratakan selama perioda pengamatan.

Apabila diketahui:

$\mathrm{N}=$ jumlah hari pengamatan

$\max \Delta a_{\mathrm{n}}(\Delta)=$ trafik tertinggi harian dari hari ke-n Maka:

$a_{\mathrm{ADPH}}=\quad \frac{1}{\mathrm{~N}} \sum_{\mathrm{n}=1}^{\mathrm{N}} \max \Delta \operatorname{an}(\Delta)$ 


\section{2) Time Consistent Busy Hour $(\mathrm{TCBH})^{[7]}$}

Dalam metode ini, dalam penentian perioda satu jam, perioda ini sama untuk setiap harinya, yang memberikan hasil pengukuran trafik rata-rata tertinggi selama perioda pengamatan

Apabila diketahui:

$\mathrm{N}=$ jumlah hari pengamatan

$a_{\mathrm{n}}(\Delta)=$ trafik rata-rata yang terukur selama interval 1-jam $(\Delta)$ pada hari ke-n

Maka:

$a_{\mathrm{TCBH}}=\max \Delta \frac{1}{\mathrm{~N}} \sum_{\mathrm{n}=1}^{\mathrm{N}} \operatorname{an}(\Delta)$

3) Fixed Daily Measurement Hour (FDMH $)^{[8]}$

Dalam perioda pengamatan telah ditentukan sebelumnya waktu pengamatan selama selang waktu 1 jam. Misalnya asumsi antara jam 9.30-10.30, trafik hasil pengukuran dirata-ratakan selama perioda pengamatan selama 10 hari.

Perhitungan FDMH ini menggunakan nilai dari TCBH yang dikalikan dengan 90\%, maka dapat ditentukan hasil standarnya dan dicari nilai yang diatas dari hasil perkalian tersebut.

$$
\mathrm{a}_{\mathrm{FDMH}}=\mathrm{a}_{\mathrm{TCBH}} * 90 \%
$$

4) Fived Daily Measurement Period (FDMP) $)^{[8]}$

Dengan metode ini pengukuran dilakukan dalam periode tertentu (misalnya 3 jam pengamatan) setiap harinya. Periode ini harus sesuai dengan intensitas trafik yang tinggi. Perhitungan FDMP ini menggunakan nilai dari TCBH yang dikalikan dengan 95\%, maka dapat ditentukan hasil standarnya dan dicari nilai yang diatas dari hasil perkalian tersebut.

$$
\mathrm{a}_{\mathrm{FDMP}}=\mathrm{a}_{\mathrm{TCBH}} * 95 \%
$$

\section{G. Penentuan Daerah BTS}

Penentuan daerah BTS ditinjau berdasarkan letak geografis, kepadatan penduduk dan kondisi alam serta seberapa banyak bangunan bertingkat. Pada batasan lingkup penelitian ini dibahas dua daerah yang mempengaruhi kinerja BTS terhadap Mobile Station (MS). Batasan daerah tersebut yaitu adalah inner city dan outer city yang ditentukan berdasarkan luas administatif pemerintahan (provinsi maupun kabupaten).

\section{1) Inner City}

Inner City adalah suatu ruang lingkup atau wilayah yang berada di pusat kota yang menjadi sentral kegiatan masyarakat. Untuk penempatan design erlang lebih besar daripada penempatan design erlang di outer city, dikarenakan populasi pelanggan lebih terfokus pada daerah ini. Dalam observasi, BTS RRI Purwokerto adalah BTS yang terletak di daerah inner city di wilayah kabupaten Banyumas. Penentuan daerah inner city dilihat berdasarkan kota Purwokerto (Kabupaten Banyumas). Tidak dilihat secara keseluruhan penentuan daerah urban yang semestinya. Karena daerah inner city di wilayah ini, mempengaruhi kinerja BTS dan dapat ditentukannya design erlang berdasarkan perumusan dari tempat observasi/Operator (PT. Telkom Divisi Flexi).
Tentunya, inner city yang berada di daerah Purwokerto berbeda dengan daerah inner city di kota lain seperti kota Jakarta dan kota-kota besar pada umumnya.

\section{2) Outer City}

Outer City adalah suatu ruang lingkup atau wilayah yang berada di pinggiran kota, dan untuk penempatan design erlang lebih kecil daripada penempatan design erlang di inner city, dikarenakan populasi pelanggan atau masyarakat lebih sedikit dibandingkan dengan populasi yang berada pada inner city. Dalam observasi, BTS Sumbang adalah BTS yang terletak di daerah outer city di wilayah kabupaten Banyumas.

Penentuan daerah outer city dilihat berdasarkan kota Purwokerto (Kabupaten Banyumas). Tidak dilihat secara keseluruhan penentuan daerah suburban yang semestinya. Karena daerah outer city di wilayah ini mempengaruhi kinerja BTS.

\section{H. Occupancy ${ }^{[7]}$}

Occupancy merupakan prosentase waktu pendudukan suatu sirkit selama jam sibuk, sehingga dapat diketahui tingkat efektifitas penggunaan kanal. Secara matematis occupancy dapat dirumuskan sebagai berikut:

$$
\text { OCC }=\frac{\text { pendudukan real time (Erlang) }}{\text { kapasitas sirkit }}
$$

Pendudukan real time disini adalah nilai rata-rata pendudukan yang dilakukan oleh pelanggan pada masing-masing interface dalam satuan Erlang. Nilai kapasitas sirkit adalah jumlah maksimal kanal yang tersedia pada masing-masing interface.

\section{ANALISIS DAN PEMBAHASAN}

Analisis ini menggunakan metode deskriptif komparasi yaitu membandingkan hasil record data total trafik dengan metode perhitungan $\mathrm{ADPH}, \mathrm{TCBH}$, FDMH dan FDMP untuk mengetahui jam sibuk antara BTS RRI PURWOKERTO (inner city) dengan BTS SUMBANG (outer city). Dari hasil data record total trafik pada BTS RRI PURWOKERTO (inner city) dan BTS SUMBANG (outer city) akan dilakukan perhitungan menggunakan metode $\mathrm{ADPH}, \mathrm{TCBH}$, FDMH, dan FDMP untuk menentukan jam sibuk diantara kedua jenis BTS tersebut (inner city maupun outer city)

\section{A. Metode Analisa yang Dipergunakan}

Untuk menentukan jam sibuk pada BTS RRI PURWOKERTO (inner city) dan BTS SUMBANG (outer city) dilakukan perhitungan dengan menggunakan beberapa metode, yaitu :

\section{1) Average Daily Peak Hour (ADPH)}

Dalam mencari nilai $a_{A D P H}$ maka dapat dilakukan dengan menggunakan persamaan 1 . Pada penentuan jam sibuk menggunakan metode ADPH langkahlangkah yang perlu dilakukan adalah mencari nilai maksimum per hari selama hari pengamatan, dan hasil maksimum yang telah didapatkan dibagi dengan jumlah pengamatan, maka didapatkan nilai $a_{A D P H}$ 
dalam satuan Erlang (Erl). Hasil maksimum per hari yang muncul akan diamati untuk menentukan jam sibuk, pada saat waktu tertentu muncul sebagai jam sibuk per harinya. Setelah ditemukan nilai maksimal dari trafik per harinya maka nilai-nilai maksimal akan dibagi dengan lamanya hari pengamatan.

\section{2) Time Consistent Busy Hour (TCBH)}

Mencari nilai $a_{T C B H}$ yaitu dengan menggunakan persamaan 2. Pada penentuan jam sibuk menggunakan metode TCBH langkah-langkah yang perlu dilakukan adalah merata-ratakan nilai dari setiap jam selama hari pengamatan, kemudian dicari hasil maksimum dari nilai rata-rata setiap jamnya. Setelah ditemukan hasil maksimum, maka didapatkan nilai $a_{T C B H}$ dalam satuan Erlang (Erl) dan penentuan jam sibuknya adalah hasil dari rata-rata tertinggi tersebut.

\section{3) Fixed Daily Measurement Hour (FDMH)}

Dalam perioda pengamatan FDMH telah ditentukan sebelumnya waktu pengamatan selama selang waktu 1 jam. Untuk menentukan jam sibuk pada metode FDMH ini menggunakan nilai dari TCBH yang dikalikan dengan $90 \%$, maka dapat ditentukan hasil standarnya dan dicari nilai yang di atas dari hasil perkalian tersebut.

\section{4) Fixed Daily Measurement Period (FDMP)}

Dengan metode ini pengukuran dilakukan dalam periode tertentu (misalnya 3 jam pengamatan) setiap harinya. Periode ini harus sesuai dengan intensitas trafik yang tinggi. Perhitungan FDMP ini menggunakan nilai dari TCBH yang dikalikan dengan 95\%, maka dapat ditentukan hasil standarnya dan dicari nilai yang di atas dari hasil perkalian tersebut.

\section{B. Perhitungan pada BTS RRI Purwokerto}

Untuk hasil maksimal BTS RRI Purwokerto ditemukan dengan menggunakan persamaan 1 diperoleh nilai $a_{A D P H}=196,063$ Erlang. Dengan nilai $a_{A D P H}$ yang diperoleh sebesar 196,063 Erlang tersbut, maka hasil ini masih tercakupi dari design Erlang yang disediakan oleh Operator untuk BTS RRI Purwokerto, yaitu sebesar sebesar 369,83 Erlang. Penentuan jam sibuk ditentukan dengan mengamati trafik tertinggi pada setiap harinya dan mendapatkan nilai kemunculannya sebanyak 4 (empat) kali pada pukul 13.00-14.00. Dengan munculnya trafik tertinggi sebanyak 4 (empat) kali pada pukul 13.00-14.00 tersebutm maka didapatkan penentuan jam sibuk menggunakan metode ADPH ditetapkan pada pukul 13.00-14.00.

Untuk mencari hasil rata-rata per jam pada BTS RRI Purwokerto dengan menggunakan motode TCBH, maka dipergunakan persamaan 2 diperoleh nilai $a_{T C B H}$ sebesar $a_{T C B H}=66,491$ Erlang. Dari hasil rata-rata per jam selama pengamatan, maka dapat ditentukan nilai maksimum dari nilai rata-rata per jam yaitu sebesar 186,145 Erlang terjadi pada pukul 13.0014.00. Nilai $a_{T C B H}$ ini masih mencakupi dengan design Erlang yang disediakan oleh Operator untuk BTS RRI PURWOKERTO yaitu sebesar 369,83 Erlang. Dengan demikian dapat ditentukan jam sibuk dengan menggunakan metode TCBH terjadi pada pukul 13.0014.00 juga.

Sedangkan dengan menggunakan metode FDMH, maka dalam menentukan jam sibuk pada metode FDMH harus mengacu kepada nilai TCBH terlebih dahulu. Berdasarkan nilai TCBH pada BTS RRI Purwokerto yang bernilai sebesar 186,145 Erlang yang kemudian dikalikan dengan 90\% maka nilai FDMH didapatkan sebesar 167,530 Erlang dan nilai ini masih mencakupi nilai design Erlang yang diberikan oleh Operator untuk BTS RRI Purwokerto yaitu sebesar 369,83 Erlang. Dalam penentuan jam sibuk, nilai satu jam sebelum terjadinya trafik tertinggi menurut konsep TCBH adalah nilai yang ditentukan untuk FDMH, dikarenakan pada satu jam sebelum terjadinya trafik tertinggi akan mengalami peningkatan intensitas trafik untuk mencapai titik puncak tersibuk selama waktu pengamatan. Jam sibuk berdasarkan nilai FDMH terjadi pada pukul 12.00-13.00 dengan nilai intensitas rata-rata selama hari pengamatan sebesar 180,739 Erlang. Nilai ini tentu saja di atas dari nilai standar dari FDMH yaitu 167,530 Erlang.

Untuk mengetahui nilai FDMP dan menentukan jam sibuk pada FDMP harus mengacu kepada nilai TCBH juga. Berdasarkan nilai TCBH pada BTS RRI Purwokerto yang bernilai sebesar 186,145 Erlang yang kemudian dikalikan dengan 95\% maka nilai FDMP didapatkan sebesar 176,838 Erlang dan nilai ini masih mencakupi nilai design Erlang yang diberikan oleh Operator untuk BTS RRI Purwokerto yaitu sebesar 369,83 Erlang. Nilai ini adalah nilai standar yang didapatkan, dari nilai standar dicari nilai yang muncul di atas dari nilai standar tersebut. Dengan masih menggunakan konsep TCBH penentuan nilai FDMP adalah nilai periode waktu yang tidak hanya terjadi dalam durasi satu jam saja dan muncul beberapa kali dalam waktu tertentu yang disebut dengan gelombang (periode) waktu. Nilai FDMP ini lebih luas daripada nilai FDMH (bisa mencakupi nilai FDMH), dikarenakan FDMP adalah penentuan jam sibuk berdasarkan gelombang waktu tertentu.

Dalam penentuan jam sibuk, penentuan jam sibuk berdasarkan gelombang waktu yang muncul dan tidak hanya satu jam saja dan memungkinkan untuk beberapa jam selama waktu pengamatan. Nilai standar yang telah dihitung akan di jadikan nilai dasar, dicari nilai lainnya yang lebih besar dari nilai dasar atau standar tersebut yang dinamakan dengan gelombang waktu pada jam sibuk menurut konsep FDMP. Periode Jam sibuk berdasarkan nilai FDMP terjadi sebanyak 3 kali yaitu pada pukul 09.00-11.00, 12.0015.00, dan 18.00-20.00. Tabel I merupakan tabel penentuan jam sibuk pada BTS RRI Purwokerto dengan Design Erlang sebesar 369.83 Erl dengan persediaan kanal sebesar 385 kanal. 
Tabel 1. Design Erlang BTS RRI Purwokerto

\begin{tabular}{|c|c|c|c|c|}
\hline $\begin{array}{c}\text { Metode } \\
\text { Perhitungan }\end{array}$ & $\begin{array}{c}\text { Nilai yang } \\
\text { Diperoleh } \\
(\mathrm{E})\end{array}$ & $\begin{array}{c}\text { Occ } \\
(\%)\end{array}$ & $\begin{array}{c}\text { Kanal } \\
\text { yang } \\
\text { Dipakai }\end{array}$ & Jam Sibuk yang Muncul \\
\hline ADPH & 196.063 & 53.01 & 210 & $13.00-14.00$ \\
\hline TCBH & 186.145 & 50.33 & 200 & $13.00-14.00$ \\
\hline FDMH & 167.530 & 45.30 & 182 & $12.00-13.00$ \\
\hline FDMP & 176.836 & 47.82 & 191 & $\begin{array}{c}09.00-11.00,12.00-15.00 \\
\& 18.00-20.00\end{array}$ \\
\hline
\end{tabular}

Berdasarkan hasil perhitungan menggunakan empat metode (ADPH, TCBH, FDMH \& FDMP), nilai keefektifan kanal pada BTS RRI Purwokerto berada diantara 21\%-69\%. Nilai ini adalah nilai yang efektif dalam penggunaan kanal yang ditentukan oleh tempat observasi/Operator (PT. Telkom Divisi Flexi). Selisih nilai dari yang tertinggi dengan yang terendah adalah 28.533 Erl atau 28 kanal.

\section{Perhitungan pada BTS SUMBANG}

Untuk hasil nilai $a_{A D P H}$ pada BTS SUMBANG dengan menggunakan persamaan 1 diperoleh hasil $a_{A D P H}=89,995$ Erlang. Nilai $a_{A D P H}$ yang diperoleh ini masih tercakupi dari design Erlang yang disediakan oleh Operator untuk BTS SUMBANG, yaitu sebesar 241,8 Erlang. Penentuan jam sibuk ditentukan dengan mengamati trafik tertinggi pada setiap harinya dan mendapatkan nilai kemunculannya sebanyak 4 (empat) kali pada pukul 19.00-20.00 dan 20.00-21.00. Dengan munculnya trafik tertinggi sebanyak 4 (empat) kali pada pukul 19.00-20.00 dan 20.00-21.00 ditetapkan penentuan jam sibuk menggunakan metode ADPH terjadi pada pukul 20.00-21.00. Dikarenakan pada pukul 19.00-20.00 adalah awal pergerakan peningkatan trafik komnikasi yang akan memuncak pada satu jam setelahnya.

Sedangkan untuk mencari hasil nilai $a_{T C B H}$ diambil nilai rata-rata per jam pada BTS RRI PURWOKERTO menggunakan persamaan 2, yang akhirnya diperoleh nilai $a_{T C B H}=36,888$ Erlang. Dari hasil rata-rata per jam selama hari pengamatan, maka dapat ditentukan nilai maksimum dari nilai rata-rata per jam yaitu sebesar 82,157 Erlang terjadi pada pukul 19.00-20.00. Nilai TCBH ini masih mencakupi dengan design Erlang yang disediakan oleh Operator untuk BTS SUMBANG yaitu sebesar 241,8 Erlang. Maka dapat ditentukan jam sibuk dengan menggunakan metode TCBH selama pengamatan hari terjadi pada pukul 19.00-20.00.

Untuk mengetahui nilai FDMH dan menentukan jam sibuk pada FDMH harus mengacu kepada nilai TCBH terlebih dahulu. Berdasarkan nilai TCBH pada BTS SUMBANG yang bernilai sebesar 82,157 Erlang yang kemudian dikalikan dengan $90 \%$ maka nilai FDMH didapatkan sebesar 73,941 Erlang dan nilai ini masih mencakupi nilai Design Erlang yang diberikan oleh Operator untuk BTS SUMBANG yaitu sebesar 241,8 Erlang. Nilai ini adalah nilai standar yang didapatkan, dari nilai standar dicari nilai yang muncul di atas dari nilai standar tersebut.
Dengan masih menggunakan konsep TCBH biasanya FDMH adalah nilai satu jam sebelum terjadinya peningkatan untuk trafik tertinggi. Maka nilai satu jam sebelum terjadinya trafik tertinggi menurut konsep TCBH adalah nilai yang ditentukan untuk FDMH, dikarenakan pada satu jam sebelum terjadinya trafik tertinggi akan mengalami peningkatan intensitas trafik untuk mencapai titik puncak tersibuk selama waktu pengamatan. Jam sibuk berdasarkan nilai FDMH terjadi pada pukul 18.00-19.00 dengan nilai intensitas rata-rata selama hari pengamatan sebesar 77,046 Erlang. Nilai ini tentu saja di atas dari nilai nilai standar dari nilai FDMH yaitu 73,941 Erlang.

Sedangkan dengan mempergunakan metode FDMP maka nilai $a_{F D M P}$ dan penentuan jam sibuknya harus mengacu kepada nilai TCBH terlebih juga. Berdasarkan nilai TCBH pada BTS SUMBANG yang bernilai sebesar 82,157 Erlang yang kemudian dikalikan dengan 95\% maka nilai FDMP didapatkan sebesar 78,049 Erlang dan nilai ini masih mencakupi nilai design Erlang yang diberikan oleh Operator untuk BTS SUMBANG yaitu sebesar 241,8 Erlang. Nilai ini adalah nilai standar yang didapatkan, dari nilai standar dicari nilai yang muncul di atas dari nilai standar tersebut.

Dengan masih menggunakan konsep $\mathrm{TCBH}$ penentuan nilai FDMP adalah nilai periode waktu yang tidak hanya terjadi dalam durasi satu jam saja dan muncul beberapa kali dalam waktu tertentu yang disebut dengan gelombang (periode) waktu. Nilai FDMP ini lebih luas daripada nilai FDMH (bisa mencakupi nilai FDMH), dikarenakan FDMP adalah penentuan jam sibuk berdasarkan gelombang waktu tertentu. Konsep FDMP tidak jauh berbeda dengan konsep FDMH, hanya saja FDMP adalah penentuan jam sibuk berdasarkan gelombang waktu yang muncul dan tidak hanya satu jam saja dan memungkinkan untuk beberapa jam selama waktu pengamatan. Nilai standar yang telah dihitung akan dijadikan nilai dasar, dicari nilai lainnya yang lebih besar dari nilai dasar atau standar tersebut yang dinamakan dengan gelombang (periode) waktu pada jam sibuk menurut konsep FDMP. Periode jam sibuk berdasarkan nilai FDMP terjadi hanya 1 kali dengan durasi waktu 2 jam yaitu pada pukul 19.00-21.00.

Tabel 2 merupakan penentuan jam sibuk pada BTS SUMBANG dengan design Erlang sebesar 241.8 Erl dengan persediaan kanal sebesar 256 kanal. Berdasarkan hasil perhitungan menggunakan empat metode (ADPH, TCBH, FDMH \& FDMP), nilai keefektifan kanal pada BTS SUMBANG Purwokerto berada diantara 21\%-69\%. Nilai ini adalah nilai yang efektif dalam penggunaan kanal yang ditentukan oleh tempat observasi/Operator (PT. Telkom Divisi Flexi). Selisih nilai dari yang tertinggi dengan yang terendah adalah 16.054 Erl atau 13 kanal. Dengan demikia nilai keefektifan kanal antara inner city dengan outer city bernilai sama. 
Tabel 2. Design Erlang BTS SUMBANG

\begin{tabular}{|c|c|c|c|c|}
\hline $\begin{array}{c}\text { Metode } \\
\text { Perhitungan }\end{array}$ & $\begin{array}{c}\text { Nilai yang } \\
\text { Diperoleh } \\
(\mathrm{E})\end{array}$ & $\begin{array}{c}\text { Occ } \\
(\%)\end{array}$ & $\begin{array}{c}\text { Kanal } \\
\text { yang } \\
\text { Dipakai }\end{array}$ & Jam Sibuk yang Muncul \\
\hline ADPH & 89.995 & 37.22 & 103 & $19.00-20.00 \& 20.00-21.00$ \\
\hline TCBH & 82.157 & 33.98 & 94 & $19.00-20.00$ \\
\hline FDMH & 73.941 & 30.58 & 86 & $18.00-19.00$ \\
\hline FDMP & 78.049 & 32.28 & 90 & $19.00-21.00$ \\
\hline
\end{tabular}

\section{Perhitungan Nilai Occupancy}

Occupancy merupakan prosentase waktu pendudukan suatu sirkit selama jam sibuk, sehingga dapat diketahui tingkat keefektifan penggunaan kanal. Perhitungan nilai occupancy dapat mempergunakan persamaan 5. Pendudukan real time pada persamaan 5 tersebut merupakan nilai rata-rata pendudukan yang dilakukan oleh pelanggan pada masing-masing interface dalam satuan Erlang. Sedangkan nilai kapasitas sirkit adalah jumlah maksimal kanal yang tersedia pada masing-masing interface. Nilai occupancy berguna untuk mengetahui dan mengamati aktitifitas trafik yang digunakan oleh pelanggan. Dari perhitungan occupancy dapat ditentukan untuk persediaan kanal, persediaan kanal disini adalah design erlang.

Berdasarkan ketentuan yang ditetapkan oleh Operator dikatakan kondisi low occupancy terjadi apabila angka occupancy $<20 \%$ (tidak efektif), normal occupancy apabila angka occupancy diantara $21 \%$ $69 \%$ (efektif), dan high occupancy apabila angka occupancy $>70 \%$ (sangat efektif). Angka ini menunjukkan kondisi kepadatan trafik yang memerlukan pengamatan yang intensif agar tidak terjadi loss traffic.

Apabila nilai occupancy melebihi dari angka 90\% secara terus-menerus dan angka peningkatan trafik semakin tinggi selama pengamatan yang dilakukan maka dibutuhkan tindakan untuk menambah design erlang secara merata dengan memperhatikan BTS lainnya. Untuk menentukan keefektifan kanal pada BTS RRI Purwokerto (inner city) dan BTS SUMBANG (outer city) maka dilakukan perhitungan occupancy dengan menggunakan hasil dari nilai perhitungan intensitas trafik dengan metode ADPH, TCBH, FDMH, dan FDMP sebagai berikut :

\section{1) BTS RRI Purwokerto (inner city)}

Operator memberikan design erlang untuk BTS RRI PURWOKERTO yaitu sebesar 369,83 Erlang. Maka nilai tersebut akan diukur tingkat keefektifan dengan membagi nilai dari kanal yang digunakan menggunakan metode berikut :

\section{- Occupancy ADPH}

Berdasarkan perhitungan trafik pada pengamatan di BTS inner city menggunakan metode ADPH didapatkan nilai penggunaan kanal sebesar 196,063 Erlang. Dengan mempergunakan persamaan 5 maka keefektifan kanal yang diperoleh sebesar OCC = $53,01 \%$

\section{- Occupancy TCBH}

Dengan cara yang sama, berdasarkan perhitungan trafik pada pengamatan di BTS inner city menggunakan metode TCBH didapatkan nilai penggunaan kanal sebesar 186,145 Erlang. Maka dari itu dengan mempergunakan persamaan 5 maka keefektifan kanal yang diperoleh sebesar OCC = $50,33 \%$

\section{- Occupancy FDMH}

Untuk occupancy pada metode FDMH, berdasarkan perhitungan trafik pada pengamatan di BTS inner city menggunakan metode FDMH didapatkan nilai penggunaan kanal sebesar 167,530 Erlang. Maka dari itu dengan mempergunakan persamaan 5 maka keefektifan kanal yang diperoleh sebesar OCC $=45,30 \%$

\section{- Occupancy FDMP}

Sedangkan pada motede FDMP, sebelumnya perhitungan trafik pada pengamatan di BTS inner city menggunakan metode FDMP didapatkan nilai penggunaan kanal sebesar 176,838 Erlang. Dengan mempergunakan persamaan 5 maka keefektifan kanal yang diperoleh sebesar OCC $=47,82 \%$

Berdasarkan hasil perhitungan dengan menggunakan empat metode tersebut, nilai keefektifan kanal pada BTS RRI Purwokerto berada diantara 21\%$69 \%$. Nilai ini adalah nilai yang efektif dalam penggunaan kanal yang ditentukan oleh Operator.

\section{2) BTS SUMBANG (outer city)}

Untuk BTS SUMBANG, operator memberikan design erlang sebesar 241,8 Erlang. Nilai ini akan diukur tingkat keefektifan dengan membagi nilai dari kanal yang dipergunakan dengan menggunakan beberapa metode yang sama seperti perhitungan sebelumnya. Dengan mempergunakan persamaan 5, maka secara berturutan nilai occupancy ADPH, TCBH, FDMH \& FDMP secara berturut-turut adalah sebagai berikut:

$$
\begin{aligned}
& \text { OCC ADPH }=37,22 \% \\
& \text { OCC TCBH }=33,98 \% \\
& \text { OCC FDMH }=30,58 \% \\
& \text { OCC FDMP }=32,28 \%
\end{aligned}
$$

Berdasarkan hasil perhitungan menggunakan empat metode, terlihat nilai keefektifan kanal pada BTS SUMBANG Purwokerto berada diantara $21 \%$ $69 \%$. Nilai ini adalah nilai yang efektif dalam penggunaan kanal yang ditentukan oleh Operator.

\section{KESIMPULAN}

Dari hasil perhitungan yang dilakukan menggunakan empat metode yaitu ADPH, TCBH, FDMH, dan FDMP didapatkan hasil penentuan jam sibuk yang berbeda antara BTS RRI PURWOKERTO 
(inner city) dengan BTS SUMBANG (outer city). Disamping itu juga didapatkan tingkat keefektifan penggunaan kanal. Dari keseluruhan analisis tersebut dapat diambil beberapa kesimpulan sebagai berikut:

- Hasil dari masing-masing metode mempunyai nilai yang bervariasi sehingga mempunyai karakteristik yang berbeda pula, dengan demikian berdasarkan nilai dari masingmasing metode dapat disimpulkan sebagai berikut :

$$
\mathrm{aFDMH} \leq \mathrm{aFDMP} \leq \mathrm{aTCBH} \leq \mathrm{aADPH}
$$

- $\quad$ Pada BTS RRI PURWOKERTO (inner city) didapatkan jam sibuk menggunakan metode perhitungan ADPH, TCBH, FDMH, dan FDMP yang didominasi antara jam 12.0015.00, sedangkan pada BTS SUMBANG (outer city) didapatkan jam tersibuk menggunakan metode perhitungan ADPH, TCBH, FDMH, dan FDMP yang didominasi pada jam 18.00-21.00. Perbedaan jam sibuk antara BTS inner city dengan BTS outer city dikarenakan dari letak BTS itu sendiri yang sangat mempengaruhi aktifitas pelanggan yang mengakibatkan jumlah trafik meningkat pada waktu tertentu.

- Berdasarkan perhitungan occupancy BTS inner city dan BTS outer city didapatkan nilai yang berada diantara 21\%-69\% yang artinya nilai ini adalah efektifnya kanal yang digunakan

\section{DAFTAR PUSTAKA}

[1] Wisanggeni, R. Haryo, dan Azhardiaz Budiman Pengembangan Riset dan Jaringan CDMA dan NGN Melalui Huawei-UI Research and Training Center. http://staff.ui.ac.id/internal/

132127785/publikasi/EII07Paper\%20Final.pdf diakses pada 25 Juni 2011.

[2] PT. Telekomunikasi Indonesia, Tbk. PL5-Planning \& Desaign Radio Access Network (RAN). http://www.scribd.com/

document downloads/direct/26923044?extension=pdf $\& \mathrm{ft}=1309 \overline{3} 37323 \& \mathrm{lt}=1309340933 \& u a h \mathrm{k}=\mathrm{bKwDOtzB}$ +kvMtpNOPn3mb60N5ts. diakses pada 29 Juni 2011.

[3] Hikmaturokhman, Alfin. 2006. Diktat Teknik Seluler. Akatel Sandhy Putra Purwokerto.

[4] Budiyono, Eko, "Analisis Trafik Pada Sistem Telekomunikasi Selular Berbasis CDMA 2000 1X di Wilayah Semarang Kota". Universitas Negeri Semarang, 2006.

[5] Linnartz, J.-P. (2009). Cellular Telephone Networks. Dipetik Oktober 18, 2011, dari Telephone Traffic Analysis: www.WirelessCommunication.NL

[6] Zeltyn, A. M. (2005). The Palm / Erlang-A Queue, with Applications to Call Centers. Haifa: Faculty of Industrial Engineering \& Management.

[7] Setiawan, Mohammad Arif, "Analisis Performansi Interface V5.2 Dengan Metode Perhitungan (TCBH dan FDMH) Studi Kasus Di PT Telkom,Tbk Area Network Purwokerto". Akatel Sandhy Putra Purwokerto, 2011.

[8] CCITT, E.500, "Traffic Intensity Measurement Principle". Reedition of CCITT Recommendition E.500 Published in The Blue Book, Fascicle II.3 (1988). 